повысит звено популярности баяна и аккордеона и сценический имидж исполнителя.

Ключевые слова: аккомпанемент; аранжировка; эстрада; джаз; стиль; аккордеон; баян; репертуар; жанр.

STRELCHENKO K. M. Methods of play the accordion of pieces of music in pop and jazz styles.

The essence of this article lies in the practical application of an innovative approach to updating the concert repertoire of an accordionist in terms of playing pieces of light genre. Basically, this is an appeal to that period when the instrumental arrangements of songs and dances were the basis for the formation of the performing repertoire for the accordion. If these instruments from the very beginning of their development were used to play music of light genres, that is, pop music, and this process contributed to the full popularization of instruments, then the musician should pay attention to the obligatory presence of pop pieces in his concert program and try to adapt arrangements accordin for modern stylistic requirements.

The development of world performing art gives rise to new genres and styles, and modernity actualizes and expands the sphere of their study.

The article reveals the key issues of the proposed methodology for performing works of pop-jazz styles on the button accordion and accordion, to expand the stylistic boundaries of the concert repertoire of the musician-teacher and musician-performer, to increase the power of impression of copyright finds in the preparation and execution of pop and jazz improvisation and arranging musical works in non-original genres and styles for them, adapting to their own performance and the capabilities of the button accordion and accordion. All this is the basis for demonstrating the original sound of the instrument and has a great advantage in terms of maintaining the popularity of the instrument repertoire of accordionists and accordionists. Updating the concert repertoire of the musician-teacher and musician-performer in the sense of stylistic enrichment with light genre music will significantly increase the link of the accordion and accordion and the stage image of the performer.

Keywords: accompaniment; arrangement; jazz; style; accordion; repertoire; genre.

DOI: https://doi.org/10.31392/NZ-npu-142.2019.25

УДК 378.091.3-051:78(477)(092)

Ткачук В. В.

\title{
МЕТОДИЧНІ ЗАСАДИ ВИКОРИСТАННЯ МИСТЕЦЬКО-ПЕДАГОГІЧНОГО ДОРОБКУ М. КОЛЕССИ У ФАХОВІЙ ПІДГОТОВЦІ МАЙБУТНІХ УЧИТЕЛІВ МУЗИКИ
}

Стаття присвячена аналізу багатогранної діяльності М.Колесси - одного 3 найвидатніших українських музикантів ХХ століття - композитора, диригента, педагога, просвітителя. Музичний доробок композитора досліджується з огляду на події його життя, а також крізь призму сочіально-культурного фону, який супроводжував його діяльність протягом багатьох років. Окреслюються основні напрямки впровадження у навчальний процес фахової підготовки студентів музичної спадщини М. Колесси, а також його педагогічної системи виховання диригента. Вивчати композиторський доробок М. Колесси варто з позииій професійного осмислення народної творчості, поєднання народно-пісенної традииії 3 сучасними стильовими експериментами. Розкрито педагогічний потенціал інструментальних 
творів композитора, окреслено методичні прийоми їх опрацювання.

У статті представлено постать М. Колесси у контексті вітчизняної виконавськохорової традииії, а також оперно-симфонічної практики. Проаналізовано педагогічні принципи М. Колесси як засновника власної диригентської иколи. Методичні засади використання педагогічного доробку композитора розкрито як через вивчення його теоретичних праць та підручників, так і шляхом осмислення власного досвіду спілкування.

Творче переосмислення М. Колессою українського фольклору яскраво проявилося у його фортепіанному доробку, який став окрасою навчального й концертного репертуару майбутніх музикантів-педагогів. Самобутній спосіб мислення композитора та оригінальність його жанрово-стилістичних прийомів характерні для фортепіанних прелюдів, написаних в різні часи. Принции універсальності диригентської підготовки, висловлений М. Колессою, відкриває для диригентів-хоровиків нові можливості щодо розщирення кола власних професійних можллиостей на ниві оркестрового диригування, а навчальним закладам музично-педагогічного профілю дає змогу сміливо впроваджувати нову кваліфікацію диригента симфонічного оркестру у підготовку магістрантів.

Ключові слова: мистецький доробок, диригентська икола, педагогічна діяльність М. Колесси.

Бурхливий розвиток музичного мистецтва в Україні у XX столітті зобов'язує нас до більш глибокого вивчення вітчизняного музично-творчого процесу, його теоретичного осмислення, а також вироблення практичних рекомендацій щодо удосконалення на його основі навчання і виховання майбутніх педагогів-музикантів.

Сучасні українські композитори та музичні діячі М. Скорик, Є. Станкович, В. Сільвестров, В. Зубицький та інші створювали свою систему музичних образів, виробляючи сучасні новаторські риси музичної мови та форми, спиралися на кращі зразки вітчизняної професійної музики М. Леонтовича, Л. Ревуцького, С. Людкевича, Б. Лятошинського. Особливе місце у цій славній когорті належить М. Колессі - композитору, диригенту, педагогу, постать якого варто розглядати у контексті національної виконавсько-хорової традиції. Музичний доробок та навчальні настанови цього видатного послідовника М. Лисенка та, водночас, сучасного музичного діяча мають увійти у вузівський художньо-педагогічний процес значно повніше та глибше, ніж це є сьогодні.

М. Колесса народився у 1903 році у м. Самбір Львівської області у родині Філарета Колесси - видатного вченого, композитора, громадського діяча. Батько композитора був класиком світової фольклористики, одним 3 найвідоміших вітчизняних музикознавців та етнографів.

Він вивчав українську пісню в її історичному розвитку, досліджував зв'язок іï поетичного і музичного змісту. В центрі уваги дослідника були проблеми еволюції українського музичного стилю, регіональні фольклорні відмінності, поетико-стилістичні та музичні особливості народних дум. Важко переоцінити глибину і значущість внеску Ф. Колесси у вітчизняну фольклористику, а також важливість розроблених та науково обґрунтованих вченим вимог до збирання, дослідження і видання народних пісень. Значний інтерес представляє також композиторський доробок Ф. Колеси - обробки українських народних пісень, хорові твори. Та в ракурсі цієї статті особливо важливим видається вплив родинного оточення та сімейного середовища на становлення особистості майбутнього музиканта й педагога.

М. Колесса отримав музичну освіту у Празькій консерваторії, яку він 
закінчив по класу композиції та диригування, а також паралельно закінчив фрілософський фракультет Празького (Карлова) університету на відділі музикології. 31928 по 1931 роки молодий музикант удосконалювався з композиції у Празькій школі вищої майстерності. Його викладачі О. Шин, П. Дєдечек, В. Новак відзначали неабиякий талант українського студента, його блискучі успіхи у диригуванні та композиції, які відзначались зв'язком з українською народною пісенністю (яскраво проявилась у випускному творі "Українська сюїта"), прагненням втілити національну ідею у класичних інструментальних жанрах (“Пасакалія, скерцо і фуга"для фрортепіано).

Повернувшись після навчання до Львова, М. Колесса викладав у Вищому музичному інституті ім. М. Лисенка,вів теорію музики, сольфеджіо, диригування. Одночасно молодий музикант яскраво проявив себе як хормейстер, працюючи 3 самодіяльними хоровими колективами “Львівський боян", “Бандурист", "Стрийський боян". Згодом М. Колеса був запрошений до Львівської фрілармонії на посаду диригента симфонічного оркестру (перший виступ в цій ролі відбувся у 1940 році), пізніше музикант отримав змогу реалізувати свій диригентський дар в оркестрі Львівського оперного театру.

З 1953 до 1965 рр. М. Колесса був ректором Львівської консерваторії імені М. В.Лисенка, усе життя його було пов'язано з цим навчальним закладом. Професор М. Колесса виховав таких видатних митців як С. Турчак, Ю. Луців, І. Гамкало, М. Антків та ін., які представляють диригентську школу уславленого маестро у кращих музичних колективах України.

Усі визначені культуротворчі досягнення М. Колесси, його музична спадщина, цілісна педагогічна система виховання диригента мають широко впроваджуватись у навчальний процес підготовки фахівців музичнопедагогічного профілю в різних видах музичної діяльності.

Фахова підготовка майбутніх учителів музики містить музично-теоретичну, інструментально-виконавську, вокальну та диригентську складові.

Аналіз художньо естетичних поглядів М. Колеси та вивчення його композиторського доробку в курсі “Історія української музики” варто пов'язувати з духовним життям Галичини XX століття: від 20-30 років, через 50-60-ті і до останнього періоду творчості митця. Музичному стилю композитора притаманні “синтез національного архетипу з сучасним художнім експериментом", яскрава колористичність імпресіоністів, модерністські пошуки у ладо-гармонічній сфері [2, с. 112]. Та слід наголошувати на тому, що вирішальну роль у його становленні відіграла народнопісенна традиція, у руслі якої і виховувався він з дитинства (важко переоцінити в цьому плані роль його батька - Ф. Колесси). М. Колессі притаманний тип роботи з фольклором, коли автор свідомо вважає, що має нести у світ український фольклор через професійну музику. При вивченні творчості композитора потрібно звертати увагу на відмову від етнографрічної буквальності у використанні фольклорних музичних традицій, від поверхневої побутовості на користь професійного осмислення естетичного змісту зразків народної творчості. В цьому сенсі цікавою $є$ низка весільних пісень для хорів різного складу “Лемківське весілля", в яких майстерно відтворені регіональні пісенні інтонації у поєднанні із сучасною гармонічною основою та символічною театральністю весільного обряду. Доцільно також привернути увагу студентів до симфонічного твору композитора 'Українська 
сюїта", в якій яскраво виступає колорит гуцульського фольклору, особливо в останній частині - "Коломийці".

Творче переосмислення М. Колессою українського фольклору яскраво проявилося у його фортепіанному доробку, який став окрасою навчального й концертного репертуару майбутніх музикантів-педагогів. У ранньому творі, фортепіанній сюїті “Дрібнички”, композитор проявився як майстер фрортепіанної мініатюри, в якій танцювально-пісенні типи композицій, чергуючись, створюють барвисте та мальовниче полотно з яскравим мелодизмом та гострими гармонічними зворотами.

Самобутній спосіб мислення композитора та оригінальність його жанровостилістичних прийомів характерні для фортепіанних прелюдів, написаних в різні часи. Це “Фантастичний прелюд”, “Осінній прелюд”, “Гуцульський прелюд” та прелюд "Про Добуша". Вивчення цих творів М. Колесси виховує в молодих піаністів "картинне бачення звукового образу..., тонке відчуття барви, гармонічної колористики" [2, с. 174]. Усі ці модерні прийоми органічно сполучаються з народною інтонаційною основою, що дає змогу виховати у студентів гармонічний синтез традиційного та новаторського художнього мислення.

Індивідуальна манера М. Колесси особливо яскраво проявляється у циклі "Три коломийки". Вивчення цього твору сприяє фрормуванню у студентів артистичних умінь, здатності швидко переключатись 3 темпераментноіскрометного настрою на пісенно-ліричний чи примхливо-граційний.

Фортепіанним творам М. Колесси притаманні риси імпресіонізму, вивчення їх збагачує уявлення студентів щодо стильових особливостей української музики загалом та індивідуальної манери письма композитора. Яскрава колористика, барвиста гармонія, просторовість, примхливість образів - усі ці ознаки дуже виразно проявляються у “Фантастичному прелюді", навіяному образним світом “Тіней забутих предків” М. Коцюбинського. Слід звертати увагу виконавців на те, що стилістичні пошуки М.Колесси поєднують ознаки імпресіонізму та фольклоризму, картинність мислення автора трансформується у яскравий звукопис від акварельності прозорої фактури до запальних та ритмічних народних танцювальних мотивів у фоортепіанній сонатині “Слідами Добуша". Майбутнім педагогам дуже корисно буде вивчити фортепіанні п'єси М. Колесси для дітей “Скерцино”, “Поміж пастушків”, “Спи, Ксеню" та інші. Вони посіли гідне місце в педагогічному репертуарі юних музикантів та створюють міцний фундамент художньо-естетичного виховання учнів на засадах культуровідповідності та доступності.

Однією з найважливіших сфер мистецької діяльності маестро було диригування. Творчий шлях М. Колесси як диригента вражає численними здобутками - від керівника чоловічого хор "Бандурист" та "Студіо-хору" до диригента симфонічного оркестру Львівської фрілармонії та оркестру Львівської опери, художнього керівника хорової капели “Трембіта". Про майстерність М. Колесси-диригента писали численні критики, а також учні та колеги, відзначаючи благородство манери, чіткість та виразність рухів, безпомилкове відчуття пропорцій та глибоке розуміння авторського замислу.

Як відзначають музикознавці, “симфонічний репертуар М. Колесси був дуже різноманітний і охоплював музичну спадщину практично усіх епох та 
провідних національних шкіл. Звісно, головне місце в колі його зацікавлень як диригента займала українська музична класика як минулого так і сучасності" [2, с. 199]. Це твори М. Лисенка, Б. Лятошинського, В. Барвінського, К. Данькевича, Л. Ревуцького, А. Штогаренка. Своєрідним мистецьким подвигом можна назвати виконання М. Колессою симфонії-кантати "Кавказ" С. Людкевича однієї з вершин вітчизняної симфонічної музики. Це був справжній тріумфр М. Колесси-диригента.

Цілком природно, що такі успіхи в концертно-виконавській діяльності викликали у М. Колесси прагнення поділитися своїм диригентським досвідом та звернутися до педагогічної діяльності. Як свідчить сам композитор, педагогічною роботою він почав займатися іще у Празькій консерваторії, даючи приватні уроки. Після повернення на батьківщину, працюючи викладачем у Вищому музичному інституті ім. М. Лисенка, він зрозумів, що потрібен підручник з диригування, який би можна було покласти в основу виховання диригентів національної школи. Так, у 1938 р. був створений "Диригентський порадник", який не втратив актуальності й дотепер. Це видання стане у пригоді диригентам-початківцям, які починають оволодівати технікою диригування, оскільки матеріал викладений простою, доступною мовою, спрямований на вирішення практичних завдань. Ця перша спроба узагальнити власні педагогічні розвідки знайшла своє продовження у підручнику “Основи техніки диригування", який витримав декілька видань.

Підручник адресовано студентам професійних музичних навчальних закладів, в ньому підсумовані педагогічні вказівки щодо вирішення різноманітних проблем диригентського мистецтва.

Серед останніх автор вирізняє необхідність формування у студентів музичного смаку та почуття міри, темпераменту та творчої фантазії, розвитку музичних здібностей майбутніх фрахівців - музичного слуху, почуття ритму, музичної пам'яті. М. Колесса наголошує, що диригент повинен володіти собою, мати витримку та швидку реакцію. Підручник містить цінну інформацію щодо тактових рухів та жестів диригента, основних схем, показів вступу та зняття звучання, різноманітної динаміки та темпу. В даному контексті варто окреслити основні методичні засади М. Колеси, яких він дотримувався в процесі занять 3 учителями (за свідченням Ю. Луціва):

- організованість та докладність в роботі;

- відповідальне ставлення до вивчення кожного твору, уникнення розхлябаності та поверхневості;

- виховання майбутніх диригентів на міцній класичній основі;

- попередній ґрунтовний аналіз твору, що диригується, в гармонічному плані, стосовно фоорми та образно-емоційної концепції [2, с. 211];

- доброзичливе ставлення до учнів, емоційна підтримка, ненав'язливе виховання загальної культури студентів.

Означені методичні засади абсолютно не втратили своєї актуальності та можуть слугувати дороговказом для сучасних викладачів хорового диригування.

Дуже цінними видаються думки композитора щодо спеціалізації диригента: “Музична практика розподілила велику сім'ю диригентів на два великих табори: диригентів-хоровиків та оркестрових диригентів. Але $є$ багато диригентів, які 
однаково добре володіють як хоровою, так і оркестровою технікою тактування і диригування. Коли врахувати широке поле діяльності, що відкривається перед таким типом диригента, - людини всебічно освіченої, 3 широким колом інтересів, диригента-педагога й організатора музичного життя, тоді стане ясно, що саме йому слід віддати першість" [1, с. 93].

Цей принцип універсальності диригентської підготовки, висловлений М. Колессою, відкриває для диригентів-хоровиків нові можливості щодо розширення кола власних професійних можливостей на ниві оркестрового диригування, а навчальним закладам музично-педагогічного профрілю дає змогу сміливо впроваджувати нову кваліфікацію диригента симфонічного оркестру у підготовку магістрантів.

Автор статті, працюючи викладачем симфонічного диригування, завжди намагається втілювати у власній практиці високі педагогічні настанови свого вихователя - М. Колесси. Я навчався у класі видатного Маестро у Львовській консерваторії. Потрібно відзначити особливу атмосферу внутрішнього піднесення і хвилювання, в якій проходили уроки М. Колесси. На початковому етапі студенти проводили час за фортепіано, вивчаючи особливості фрактури виконуваного твору, відкриваючи його стилістичні особливості, характерні композиційні прийоми .

На першому етапі навчання М. Колесса строго рекомендував опановувати мистецтво диригування на базі класичних творів Гайдна, Моцарта, Бетховена, згодом поступово розширюючи репертуар.

В своїй роботі зі студентами основну увагу він приділяв мануальній техніці: права рука відтворює метро ритм музичного твору, ліва рука характер, динаміку, підкреслює кульмінаційні вершини. Професор наголошував, що диригент повинен дуже ретельно, пластично-виразно диригувати кожну долю схеми, пропускаючи через серце й розум, щоб музика хвилювала слухача. На уроках з учнями М. Колесса відпрацьовував кожний жест, але він приділяв увагу не тільки технічній підготовці, а й наголошував на необхідності набуття глибоких знань з гармонії та поліфонії, виховання уміння логічно вибудовувати музичну форму крупних симфонічних творів, на формуванні здатності до професійної орієнтації в трактовці різних стилів творів вітчизняних та зарубіжних композиторів.

На практичних заняттях з симфонічним оркестром Микола Філаретович вчив налагоджувати творчий контакт з оркестрантами, лаконічно пояснювати свої побажання у словесній формі, виразно доносити свій задум через диригентський жест.

Після закінчення оркестрової репетиції М. Колесса обов'язково обговорював зі студентами її перебіг та результати, уважно вислуховував кожного учня щодо характеристики власної роботи та репетиції, своїх колег, а потім виступав останнім, підсумовуючи роботу всіх, хто проводив репетиції. В разі потреби вчитель сам виходив з пульт, і під його орудою оркестр починав звучати злагоджено і натхненно. Манера диригування М. Колесси, його підхід до самої підготовки роботи з оркестром, заняття в класі цього видатного композитора, вченого, диригента, педагога, творця власної школи диригентського мистецтва назавжди залишиться в моїй пам'яті. 


\section{Використана література:}

1. Гоян Я. П. Маестро: Есе. Київ : Веселка, 2005. 207 с.

2. Кияновська Л. О. Син століття Микола Колесса в українській культурі XX віку. Львів : Дослідновидавничий центр наукового товариства ім. Т. Шевченка, 2003. 293 с.

3. Колесса Н. Ф. Основы техники дирижирования. Київ : Музична Україна, 1981. 206 с.

4. Паламарчук О. Р. Микола Колесса. Київ : Музична Україна, 1989. 76 с.

\section{References:}

[1] Hoian Y a.P. (2005). M aestro: Ese. K yiv : V eselka, $207 \mathrm{~s}$.

[2] K yianovska L. O. (2003). Syn stolittia M ykola K olessa v ukrainskii kulturi K hK h viku. L viv : Doslidnovydavnychyi tsentr naukovoho tovarystva im. T. Shevchenka, $293 \mathrm{~s}$.

[3] Kolessa N. F. (1981). Osnovy tehniki dirizhirovaniya. K yiv : M uzychna Ukraina, $206 \mathrm{~s}$.

[4] Palamarchuk O. R. (1989). M ykola Kolessa. Kyiv : M uzychna U kraina, 76 s.

ТкАчУК В. В. Методические основы использования художественно-педагогического наследия Н. Колессы в профессиональной подготовке будущих учителей музыки.

Статья посвящена анализу многогранной деятельности Н. Колессы - одного из выдающихся украинских музыкантов ХХ века - композитора, дирижера, педагога, просветителя. Музыкальное наследие композитора исследуется с учётом событий его жизни, а также сквозь призму социально-культурного фона, которьй сопровождал его деятельность на протяжении многих лет. Определяются основные направления внедрения в учебный прочесс профессиональной подготовки студентов музыкального наследия Н. Колессы, а также его педагогической системь воспитания дирижера. Изучать композиторское наследие Н. Колессы стоит с позииии профессионального осмысления народного творчества, сочетания народно-песенной традиции с современными стилевыми экспериментами. Раскрыт педагогический потенщиал инструментальных произведений композитора, определены методические приемы их изучения.

В статье фигура Н. Колессы представлена в контексте отечественной исполнительскохоровой традичии, а также оперно-симфонической практики. Проанализированы педагогические принципы М. Колессы как основателя собственной дирижерской школь. Методические основы использования педагогического наследия композитора раскрыты как через изучение его теоретических трудов и учебников, так и путем осмысления собственного опыта общения.

Творческое переосмысление М. Колессой украинского фольклора ярко проявилось в его фортепианном наследии, который стал украшением учебного и кониертного репертуара будущих музыкантов-педагогов. Самобытный образ мылиления композитора и оригинальность его жанрово-стилистических приемов характерны для фортепианных прелюдий, написанных в разные времена. Принщип универсальности дирижерской подготовки, высказанныій $H$. Колессою, открывает для дирижеров-хоровиков новые возможности по расширению круга собственных профессиональных возможностей на ниве оркестрового дирижирования, а учебным заведениям музыкально-педагогического профиля позволяет смело внедрять новую квалификаиию дирижера симфонического оркестра в подготовку магистрантов.

Ключевые слова: творческое наследие, дирижерская школа, педагогическая деятельность Н. Колессы.

TKACHUK V. V. Methodical foundations of using the artistic and pedagogical heritage of $\mathrm{N}$. Kolesa in the professional training of future music teachers.

The article is devoted to the analysis of the many-sided activities of N. Kolesa - one of the outstanding Ukrainian musicians of the twentieth century - a composer, conductor, educator of the educator. The musical heritage of the composer is explored taking into account the events of his life, as well as through the prism of the socio-cultural background, which accompanied his activities for many years. The main directions of introduction of the musical heritage of $\mathrm{N}$. K olessa's students into the educational process, as well as its pedagogical educational system of the conductor, are determined. To study the composer's 
legacy of $\mathrm{N}$. Kolessa stands from the standpoint of professional understanding of folk art, combining the folk-song tradition with modern stylistic experiments. The pedagogical repertoire, including instrumental works of the composer, is revealed, the methodical methods of their study are defined.

In the article, the figure of $\mathrm{N}$. Kolessa is presented in the context of the national performingchoral tradition, as well as opera-symphonic practice. The pedagogical principles of $\mathrm{M}$. Kolessa as the founder of his own conducting school are analyzed. The methodological foundations of the use of the composer's pedagogical heritage are revealed both through the study of his theoretical works and textbooks, as well as through the comprehension of his own experience.

The creative rethinking of U krainian folklore by M. Kolesa was clearly manifested in his piano heritage, which became the decoration of the educational and concert repertoire of future musicians and teachers. The composer's original way of thinking and the originality of his genre-stylistic devices are characteristic of piano preludes written at different times. The principle of universality of conductor training, expressed by N. Colessus, opens up new opportunities for choir conductors to expand the range of their own professional capabilities in the field of orchestral conducting, and musical and pedagogical institutions can boldly introduce the new qualification of a symphony orchestra conductor in the training of undergraduates.

Keywords: creative heritage, conductor's school, N. K olesa's pedagogical activity.

DOI: https://doi.org/10.31392/NZ-npu-142.2019.26

УДК 378.147.091.33-027.22:004

Трифонова О. М.

\section{КОНЦЕПТУАЛЬНІ ЗАСАДИ РОЗВИТКУ ІНФОРМАЦИЙНО-ЦИФРОВОЇ КОМПЕТЕНТНОСТІ МАЙБУТНІХ ФАХІВЦІВ КОМП'ЮТЕРНИХ ТЕХНОЛОГІЙ}

Стаття присвячена проблемі окреслення конщептуальних засад розвитку інформаиійноичиррової компетентності майбутніх фахівців комп'ютерних технологій. Дане дослідження набуло особливої актуальності в умовах иифрровізаиії освіти. Встановлено, що за даного стану розвитку суспільства особливої ваги набуває фактор систематизаиії інформаиії, представленої у иифровому форматі. Узагальнюючи досвід електронізачії освітнього процесу в іниих державах, визначено концепцію електронізації та иифровізації освітнього процесу. Виходячи з сучасного розуміння науково-технічного прогресу, системна автоматизачія викликала підготовку фахівия нового типу з якісно вищим рівнем професійної підготовки. Такий підхід передбачає перехід від екстенсивних до інтенсивних методів навчання фізики і технічних дисииплін на базі інформаційноцифрових технологій. На основі проведеного аналізу розробили модель засад формування методичної системи розвитку інформаційно-иифррової компетентності майбутніх фахівиів комп'ютерних технологій унавчанні фізики і технічних дисииплін.

У статті окреслено концептуальні засади розвитку інформаційно-цифрової компетентності майбутніх фахівців комп юотерних технологій.

Для досягнення поставленої мети були використані такі методи: аналіз теоретичних джерел із проблеми розвитку компетентностей, вивчення й узагальнення передового педагогічного досвіду. Визначені компоненти та модель є підгрунтям створення структури $i$ змісту професійної підготовки майбутнього фахівия спеціальності "Професійна освіта (Комп 'ютерні технологіі)" . Дотримання окреслених засад забезпечує вибір оптимальних форм, 